\title{
Improving Employee Job Satisfaction in Aviation Industry
}

\author{
Samto Hadi Isnanto \\ Faculty of Economy Nurtanio University \\ samtoisnanto@gmail.com
}

Received: October 21, 2021; Accepted : October 28, 2021; Published : November 1, 2021

\begin{abstract}
Job satisfaction is an important issue in an organization. Job satisfaction has been talked about over and over again because of the importance it has in both individual and group behaviour, which will affect in the productivity of an organization. Even though the role of job satisfaction is important in an organization, it is sometimes unnoticed and ignored by the management which in turn results in a decrease of organizational work performance. This study aims to answer why job satisfaction is important and how to improve it in aviation industry. The method used in this research is a literature review by finding specific researches that corresponds to the topic discussed, which is job satisfaction, to integrate them into a concise conclusion. This research uses samples from published journals in the last 10 years (2011-2021) found through google scholar with the main variable job satisfaction. The result of this study shows that based on the literature reviews of different journals, job satisfaction proves to strengthen employee engagement and organizational commitment, decreases the rate of employee turnover and improves employee productivity. There are a few proven ways to increase job satisfaction in aviation industry which is creating a conducive/positive work environment, applying reward and recognition management, developing the potential skills of employees and continuous evaluation and measurement of employee job satisfaction.
\end{abstract}

Keywords: employee job satisfaction, aviation industry

\begin{abstract}
ABSTRAK
Kepuasan kerja merupakan isu penting dalam sebuah organisasi. Kepuasan kerja telah dibicarakan berulang kali karena pentingnya hal itu dalam perilaku individu dan kelompok, yang akan mempengaruhi produktivitas suatu organisasi. Meskipun peran kepuasan kerja penting dalam suatu organisasi, terkadang tidak diperhatikan dan diabaikan oleh pihak manajemen yang pada akhirnya berakibat pada menurunnya kinerja organisasi. Penelitian ini bertujuan untuk menjawab mengapa kepuasan kerja itu penting dan bagaimana cara meningkatkannya di industri penerbangan. Metode yang digunakan dalam penelitian ini adalah studi pustaka dengan mencari penelitian-penelitian tertentu yang sesuai dengan topik yang dibahas yaitu kepuasan kerja, untuk mengintegrasikannya ke dalam suatu kesimpulan yang ringkas. Penelitian ini menggunakan sampel dari jurnal terpublikasi dalam 10 tahun terakhir (2011 - 2021) yang ditemukan melalui google Scholar dengan variabel utama kepuasan kerja. Hasil penelitian ini menunjukkan bahwa berdasarkan tinjauan literatur dari berbagai jurnal, kepuasan kerja terbukti memperkuat keterlibatan karyawan dan komitmen organisasi, menurunkan tingkat turnover karyawan dan meningkatkan produktivitas karyawan. Beberapa cara yang terbukti dapat meningkatkan kepuasan kerja di industri penerbangan adalah dengan menciptakan lingkungan kerja yang kondusif/positif, menerapkan manajemen penghargaan dan pengakuan, mengembangkan potensi keterampilan karyawan dan evaluasi dan pengukuran kepuasan kerja karyawan secara terus menerus.
\end{abstract}

Kata kunci: kepuasan kerja karyawan, industri penerbangan

\section{INTRODUCTION}

Job satisfaction is an important issue in an organization. Che, Zhao \& Liu states that "job satisfaction represents one of the most daunting areas being faced by today's managers when it comes to managing their employees" meanwhile Tansel \& Gazîoğlu states that "job satisfaction is a primary policy priority in any organization" [9]. 
Aviation industry is one of profitable industries. Employee in aviation industry should have performed their job with the convenience ambience. Job satisfaction can provide convenience ambience on aviation industry.

Job satisfaction has been talked about over and over again because of the importance it has in both individual and group behaviour, which will affect in the productivity of an organization. Empirical evidence of the importance of job satisfaction is that in times we see issues such as employee demonstration demanding a raise in wage, absent from work, low work motivation, and a raise in employee turnover rate. All of these issues all link to the job satisfaction of employees.

Because of the importance of job satisfaction to an organization, employee and organizational leader are not the only ones that pays special attention to it, but also academics and researchers. Job satisfaction has been researched and talked about in a lot of journals and papers. A few researches show a positive correlation both directly and indirectly of job satisfaction with other variables affecting job performance.

An example is job satisfaction and organizational commitment discussed in [4], [1], [12]. Job satisfaction affecting turnover rate researched and job satisfaction with employee involvement. [31].

Even though the role of job satisfaction is important in an organization, it is sometimes unnoticed and ignored by the management which in turn results in a decrease of organizational work performance. A global study, most problem in job satisfaction stems from: 1) pay dissatisfaction, 2) number of hours worked, 3) not getting enough personal days off and holidays, 4) lack of flexibility in the working hours, and 5) time spent commuting to and from work. [33]

This study aims to answer why job satisfaction is important and how to improve it. This research is a literature study in which the data used are journals and articles researched and published from January 2011 October 2021 and then analyzed according to the topic of the research which is employee job satisfaction.

\section{METHODOLOGY}

The method used in this research is a literature review by finding specific researches that corresponds to the topic discussed, which is job satisfaction, to integrate them into a concise conclusion. This research uses samples from published journals in the last 10 years $(2011-2021)$ found through google scholar with the main variable job satisfaction.

\section{RESULT AND DISCUSSION}

Robbins \& Judges defines job satisfaction as "a positive feelings about one's job resulting from and evaluation of its characteristics". Meanwhile Armstrong defines job satisfaction as "the attitude and feelings individuals towards their work, it can be either positive (satisfied) or negative (dissatisfied)" [9]. From the two definitions, we can conclude that if a person is satisfied with their job, which is reflected in their positive attitude and positive emotion, that person will be motivated in doing their work and will result in the increase of organizational productivity. On the other hand, if a person is unsatisfied, then it will be reflected in a negative attitude and emotion which will result in a lower work motivation and organizational productivity.

Employee dissatisfaction is further defined by Robbins [29]:

1. A behavior that will manifest by leaving the current job to find another position in other workplaces.

2. Asking the superior of the activities that cannot be met according to the condition in the workplace and proceeds on another activity to seek justification with the labor union.

3. If there is dissatisfaction in the current workplace, an employee will act passive and wait until there is a possible change.

4. The employee will continue to act passive until the situations worsens, and will then start to miss work, produce a lower work effort and increases the error rate when working.

If these conditions manifested in a group or organization, then it is clear that there is employee dissatisfaction happening and that a way to resolve this should be thoroughly planned and executed.

According to Colquitt, LePine and Wesson, job satisfaction is divided into a couple of catagories [33]:

1. Pay Satisfaction

Reflects an employee's feeling about their pay. Pay satisfaction is based on the amount they received vs the amount they expected.

2. Promotion Satisfaction

Reflects on the feeling about the promotion policy of an organization and the implementation.

3. Supervision Satisfaction

Reflects the interpersonal relationship of an employee and their leader. The feelings an employee has on their leader (whether the leader is competent or not, polite, a good communicator, diligent, etc) will greatly affect supervision satisfaction.

4. Coworker Satisfaction 
Reflects the feelings an employee has on another employee/colleague, including if the colleague is smart, responsible, helpful, etc.

5. Satisfaction with the Work Itself

Reflects an employee's feeling about their job tasks, whether their job is interesting, challenging, dynamic, etc.

6. Altruism

An act of taking pleasure in helping others or in this context helping colleagues when they have a huge number of tasks.

7. Status

Is in relation to prestige, having the power over other people, and popularity.

8. Environment

Shows the feeling of comfort and safety. A good work environment can create a quality of worklife in a workplace.

According to Goeroge and uzumdar, there are four components effect to employee job satisfaction in Airline Industry are :[14]

1. Work family conflict

2. Job Autonomy

3. Servant Leadership

4. Simphathy

A recent study by Iwu et al. found in their study regarding the teachers in the Ibadan South-West local government area in Oyo state Nigeria, that the top three variables contributing to the teacher's job satisfaction are pay/salary, growth opportunity and responsibilities attached to work [10]. What is important to note is that these conditions do not only affect the teacher but also those around them. Similarly Dalluay et al. revealed in their research findings that pay and promotion, work relationship and use of skill and ability has a positive correlation to employee's job satisfaction[5].

Knowing that job satisfaction is one of the major roles in affecting work performance of employees in an organization especially in aviation industry, this leads us to know more and understand better, why is job satisfaction important?

\section{Job Satisfaction Strengthens Employee Engagement}

Employee job satisfaction has a positive and significant correlation with employee engagement. In their study, Tepayakul and Rinthaisong stated that job satisfaction can be catagorized into two catagories which is intrinsic and extrinsic[31]. Relationship between job satisfaction and employee engagement is positive and significant. They also added that there is no significant difference between both employee engagement and job satisfaction to the gender of the respondents[32].

Intrinsic factors affecting employee satisfaction are achievement, recognition, responsibility, advancement, growth, and the work itself. Extrinsic factors include supervision, work conditions, co-workers, pay, policies, job security, status and the worker's personal life.[31].

Research done by Jenkins and Stewart in a couple of East European countries (Armenia, Kazaktan. Russia and Kirgiztan) found that there is a positive and strong correlation between the desire in the fulfillment of extrinsic motivations such as wage and work environment with the guarantee of a safe workplace. Another study shows that there is a correlation between job satisfaction and work engagement with organizational commitment. Meanwhile organizational commitment is the willingness to participate and voluntarily loyal to their organization [1].

Job autonomy is one part of factor to lead employee have strengthens engangement. The positive effect of job autonomy on job satisfaction suggests that the implementation of flexible work policies will be beneficial for the aviation sector[14]

Pahrudin, Cecep, Sandriana Marina, and Lira Agusinta $\mathrm{n}$ their research found that ini airline job characteristic have positive effect to job satisfaction[22]. In avaition industry which provide service to their customer, the flexibiity to perform the job is needed. Since the customers want to be serviced all the time. With job autonomy employee caoul manage their job and they could difine job characteristic that they want. Employee who are comfort to perform their job which ultimately will improve job satisfaction.

From the studies above, we can conclude that job satisfaction is important to an organization because a high satisfaction can improve employee engagement and the attachment between employee to their organization. Employee attachment or involvement towards their organization builds a sense of belonging to their organization, which in turn will make them care, act positive and has the motivation to actively participate in developing their organization.

\section{Job Satisfaction Strengthens Organizational Commitment}


Employee satisfaction can increase organizational commitment. Organizational commitment is the willingness and free will to participate and be loyal to their organization [1].

Job satisfaction has a positive and strong relation to organizational commitment. There are three important commitment factors which are affective commitment (commitment that stems from a close emotional bond the organization), continuance commitment (based on the perception of an employee on the amount of loss they will receive if they leave the company), and normative commitment (related to the employee's feeling on the need to stay in an organization[33].

In relation to the dimensions of commitment explained in their study on civil servants of city halls found that affective commitment shows a positive and significant relation with satisfaction, whereas normative commitment shows a negative relation with satisfaction. This shows that an emotional bond with the organization proves to be an important factor in affecting the employee's satisfaction[17].

Abu-Shamaa, Al-Rabayah and Khasawneh found in their research that there is a positive relation between job satisfaction and employee involvement with organizational commitment [1]. Organizational commitment is needed by all employees. Without a good commitment, then an employee can harm an organization by acting on their own because there is no sense of belonging to their organization. For example, an employee not coming to work because of an unreasonable reason or coming to work just to get a good evaluation for their attendance report.

An employee with a high commitment will most definitely work with a high motivation to achieve their designated work target even when unsupervised. A previous study by Srivasta also showed the same findings that job satisfaction has a positive correlation with organizational commitment and trust[27].

\section{Job Satisfaction Decrease the Rate of Employee Turnover}

Employee turnover rate has been a challenging issue that every organization must face nowadays. There are a lot of reasons why employee decides to leave the organization, one of them is because of dissatisfaction with their job. Jarupathirun and De Gennaro found in their study that the main factors contributing to the intention to leave are recognition, relationship with peers, remuneration and work security[11]. From the study they concluded that various workplace and demographic factors prove to be important in affecting job satisfaction and turnover rate, and suggested that managers/leaders should monitor employee's perception of their work and work environment as these factors has a causal relationship with productivity which will affect the organization's success.

Chhabra in his study found that there is a negative correlation between job satisfaction and turnover which is mediated by organizational commitment[4]. This finding is similar to the result of a study by Ekhsan where job satisfaction has a negative and significant effect on turnover intention. Ekhsan also added that job satisfaction and organizational commitment both simultaneously effects turnover intention significantly[7].

The leader of an organization must realize and understand that the turnover of an employee can result in a loss for a company, especially talented employees. Maintaining employee can create a conducive work environment due to the less worry the employees have on losing their job (job security). The main point is that a person usually tries to find a work place beneficial to their wellbeing both physically and mentally. Which is why it is understandable that if an employee is unsatisfied then they will find another place that can give the satisfaction they need.

\section{Improves Employee Productivity}

Employees who are emotionally satisfied will feel comfortable and happy because their intrinsic and extrinsic expectations are being fulfilled. This condition will be a stimulus or drive to increase work motivation in employees which ultimately will increase productivity. An employee who feels fulfilled and is happy will manifest a positive behaviour. An example is that if an employee works in serving the customers, then by being satisfied in their job, that employee will manifest a positive behavior such as emitting a happy and friendly attitude when serving the customers. That kind of service will of course attract more customers and increase the income for the company. Another example is an employee in production. Being fulfilled and happy can increase their work motivation and spirit which will in turn increase their amount of production. In conclusion, an increase in job satisfaction will increase productivity, which ultimately will result in an increase in company profit.

Robbins and Judge explained that dissatisfaction in an employee can result in a few responses which are: 1) Exit (an immediate response by leaving the organization), 2) Voice (actively participates in voicing constructive feedbacks for the organization through various ways such as corrective suggestions, discussion with their superior, and through activities by the union), 3) Loyalty (being optimistic about the way an organization work and their policy, trusting the leader, management, and organization), 4) Neglect (decreasing their effort, the increase of error rate, chronic absence and tardiness.[33] 
Now that the importance of job satisfaction has been explained and understood, we must also understand the ways on how to increase job satisfaction. Increasing job satisfaction is a job for the company's management. In aviation industry job satisfaction is employee needs, since the aviation industry is one of service company. Employee with good job satisfaction could perform their job with happy, it is mean they could service their customer with good experiences. Every organization leader must realize that employee job satisfaction is an important and powerful determinant in an organization. It has been explained above that employee job satisfaction can increase productivity which will result in the increase of company income. Company income can also be defined as the increase of stakeholder's welfare both externally and internally. The question is, how do we increase employee job satisfaction? There are at least four steps that company management must undergo in order to increase employee job satisfaction, which are: creating a conducive/positive work environment, apply reward and recognition management, developing the potential skills of employees, and a continuous evaluation and measurement of employee job satisfaction as a leadership benchmark.

\section{Create a Conducive/Positive Work Environment}

There is a large scope when talking about work environment, however there is two main grouping which is physical and non-physical work environment. Physical work environment include: adequate room, sufficient ventilation, the availability of supporting work equipments, and so on. On the other hand, examples of nonphysical work environments are: interpersonal relationship between employees and employee-leader relationship. A conducive work environment can lead to an increase in employee job satisfaction. Lavy and Bocker found in their research that there is a positive influence between a teacher-student interaction to the teacher's job satisfaction.[16]

Other studies such as by Pawirosumarto, S., Sarjana, P.K. and Gunawan and Shobe also supports that work environment has a positive and significant impact on job satisfaction.[23][26] Whereas Permadi, Landra and Kusuma, I Gusti Agung Eka Teja Sudja found that work environment along with compensation partially has a positive influence to job satisfaction.[24] Kafui Agbozo also added that it is important for the management of an organization to improve the work environment in order to boost employee job satisfaction and productivity.[13] Work environment, along with reducing stress level and job satisfaction can be policy tools to reduce the turnover intention in an organization. [15]

\section{Apply Reward and Recognition Management}

Reward and recognition in an employee's contribution play an important role in employee motivation. Give them reward for their work performance and openly praise them for their contribution in making the company better. Do not openly criticize their low work performance in front of other people, but give a proper evaluation and suggestions to improve it. Openly criticizing them will only lower their work motivation and loyalty to the company. Ahmad and Jameel found in their study that reward placed as second highest on the factors affecting job satisfaction, whereas job security placed the highest.[2]

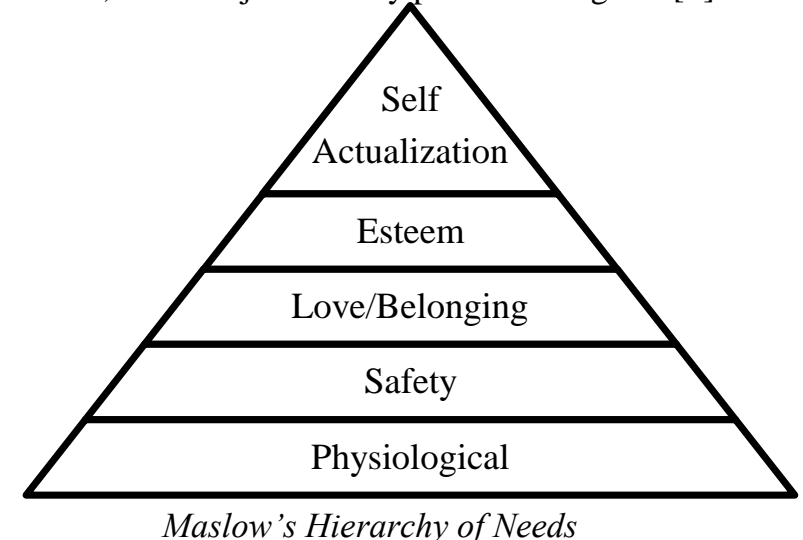

Maslow hierarchy of needs shows that reward is in the second highest place just below self actualization. This shows that reward also plays an important part in motivating a person. Fortuna found that reward has an important role in motivating kitchen hospital employee in RSAU dr. Esnawan Antariksa and has a significant and positive relationship with work performance. Fortuna also found that reward, as one of the factors to increase motivation, has a high and significant chance in increasing employee performance[8]. Another study by Dobre, Davidescu and Issa Eid on 325 employees in six Jordan hospitals states that financial stimulus is not the only factor that increases motivation, but non-financial stimulus also plays an important role[6]. Martono, Khoiruddin and Wulansari also supports that reward proves to be a factor that increases motivation in employee. From these researches we can conclude that reward both financially and non-financially, for example in the form of recognition, is an important factor in motivating employee which when fulfilled, is 
considered fulfilling one of the basic human needs from Maslow's hierarchy of needs, results in an increase to their job satisfaction[20].

\section{Developing the Potential Skills of Employees}

Jehanzeb and Mohanty in their study found that employee development methods such as training and education can increase job satisfaction[12]. The conclusion in their study is that job satisfaction has a positive correlation with organizational commitment. Okechukwu added that training and development and employee performance is an efficient supportive strategy to a successful employee and organization[21]. Their study found that training and development along with employee performance influence job satisfaction positively and that there is a significant relationship between the three factors. Chaudhry and Bhaskary similarly also found a positive relationship between employee training and development and job satisfaction[3]. They also noted that employees who undergo training and development courses feel that their active parts and skills has improved.

As a leader, it is an obligation to keep on improving the ability and skills of their employee to increase their productivity. Employee with high productivity is usually in conjunction with a high motivation. A study in Pakistan shows that there is a positive impact between the initiative to improve employee skills to organizational commitment, thus why the leaders of companies must plan and implement well the employee development program in order to improve employee job satisfaction[12]..

\section{Continuous Evaluation, Supervision and Measurement of Employee Job Satisfaction as a Leadership Benchmark}

Employee job satisfaction evaluation can be used as one of the means to measure the success of a leadership in an organization. Setyaningsing, Yesa Martha Vita Simanungkalit Endang found in her research in PT. Lion Mentari Airline, leadership characteristic effect job satisfaction but not significant [25]. The leader must implement continuous evaluation to understand how far the condition of job satisfaction in their organization is currently. As explained before, job satisfaction is closely related to employee performance, and employee performance is closely related to productivity. In order to undergo job satisfaction evaluation and control, there are certain indicators evaluated which are: behavior, moral and motivation.

Identifying the problems affecting their job satisfaction is important in improving it. For example, is the work environment conducive? is the compensation fair? How is the carreer management? How is the leadership? and if the work is monotone or not. Find the problem instigating it and make improvements so that employee's work satisfaction can increase. A study in the US shows that personality can partly show the condition of job satisfaction. (Templer, 2012[30]

Stoner, Freeman and Gilbert states that "control is a process of ensuring that actual activities conform the planned activities' [28]. In other word, supervision is a process to ensure that every activity that happens goes according to the plan. In order to keep job satisfaction at the optimal level, organizational management must continue to supervise and evaluate the factors surrounding it and correcting the problems that arise. Sule and Saefullah further explains that the importance of supervision in management is a systematical way in establishing job performance standard and other goals that has been planned out and also to take necessary actions in ensuring that every resource in the company is efectively and efficiently used to achieve the company's goal[28].

There are three important key points in understanding how human resources is supervised and controlled. The three key points are motivation, satisfaction and leadership. Every organization/company must understand, supervise and control the motives that encourage employees and the level of satisfaction they expect. After understanding the motivation and satisfication factors, the next step is to take control measures according to the condition of the employees. This is then where leadership plays and important role as leadership style directly affects the ways a leader will handle a certain situation.

\section{CONCLUSION}

Employee satisfaction is an important factor in increasing organizational performance. Especially in aviation industry which provide service to their customer. Employee with job satisfaction could perform their better and they could serve their customer with good experience. Employee satisfaction can decrease turnover rate, increase employee engagement, increase organizational commitment and productivity.

There are a few ways to increase employee job satisfaction which are: creating a conducive/positive work environment, implementing reward and recognition management, increase the potential skills of employees, and continuous evaluating and measuring employee's job satisfaction.

It is imperative that the leader of an organization to continuously observe and strive to increase employee satisfaction. Consider routine evaluation, for example yearly evaluation through internal survey to 
Improving Employee Job Satisfaction in Aviation Industry

measure the development of employee satisfaction. Immediately tackle any problems that possess a threat to employee satisfaction as soon as possible to prevent the decline in employee job satisfaction.

\section{REFERENCES}

[1] Abu-Shamaa, R., Al-Rabayah, W. A. and Khasawneh, R. T., "The effect of job satisfaction and work engagement on organizational commitment", The Journal of Applied Business Research, 15(4), pp. 7-27, 2015. [2] Ahmad, M. and Jameel, A., "Factors Affecting on Job Satisfaction among Academic Staff", Polytechnic Journal, 8(2), pp. 119-128. , 2018, doi: 10.25156/ptj.2018.8.2.161.

[3]Chaudhry, N. . and Bhaskary, P., "Training and Development and Job Satisfaction in Education Sector", Journal of Resource Development and Management, 16, pp. 42-45, 2016.

[4] Chhabra, B., "Person-Job Fit: Mediating Role of Job Satisfaction \& Organizational Commitment", Indian Journal of Industrial Relations, 50(4), p. 638, 2015.

[5] Dalluay, V. et al. , "The Impacts of Job Satisfaction on Employee Turnover: A Case Study of Oman Air in Sultanate of Oman", European Academic Research, V(1), pp. 331-374, 2017.

[6 Dobre, I., Davidescu, A. A. and Issa Eid, M. T., "Key Factors of Health Employee Motivation in Jordan. Evidence From Dual-Factor Theory Based on Structural Equation Models", Economic Computation and Economic Cybernetics Studies and Research, 51(2), pp. 39-54, 2017.

[7] Ekhsan, M., "The Influence Job Satisfaction and Organizational Commitment on Employee Turnover Intention", Journal of Business, Management, and Accounting, 1(1), pp. 48-55, 2019, Available at: http://ejournal.stie-kusumanegara.ac.id.

[8] Fortuna, I. D., "Hubungan Beban Kerja, Stres Kerja dan Motivasi dengan Kinerja Karyawan Dapur Gizi Pada Masa Pandemi COVID-19 di RSAU dr. Esnawan Antariksa Jakarta", Universitas Respati Indonesia, 2021.

[9] Inuwa, M., "The Impact of Job Satisfaction, Job Attitude and Equity on Employee Performance", The International Journal Of Business \& Management, 3(5), p. 7, 2015.

[10] Iwu, C. G. et al., "Achieving quality education by understanding teacher job satisfaction determinants", Social Sciences, 7(2), 2018, doi: 10.3390/socsci7020025.

[11] Jarupathirun, S. and De Gennaro, M. ,"Factors of work satisfaction and their influence on employee turnover in Bangkok, Thailand", International Journal of Technology, 9(7), pp. 1460-1468, 2018, doi: 10.14716/ijtech.v9i7.1650.

[12] Jehanzeb, K. and Mohanty, J., "Impact of employee development on job satisfaction and organizational commitment: person-organization fit as moderator", International Journal of Training and Development, 22(3), pp. 171-191, 2018, doi: 10.1111/ijtd.12127.

[13] Kafui Agbozo, G., "The Effect of Work Environment on Job Satisfaction: Evidence from the Banking Sector in Ghana", Journal of Human Resource Management, 5(1), p. 12. , 2017, doi: 10.11648/j.jhrm.20170501.12.

[14] Kurian, Goerge and Prathamesh Muzumdar., "Antecedets to Job Satisfactio in Airline Industry", NMIMS Management, Volume XXXIV | Issue 2, p29-40, 2017.

[15] Kurniawaty, K., Ramly, M. and Ramlawati., "The effect of work environment, stress, and job satisfaction on employee turnover intention", Management Science Letters, 9(6), pp. 877-886, 2019, doi: 10.5267/j.msl.2019.3.001.

[16] Lavy, S. and Bocker, S., "A Path to Teacher Happiness? A Sense of Meaning Affects Teacher-Student Relationships, Which Affect Job Satisfaction", Journal of Happiness Studies, 19(5), pp. 1485-1503, 2018, doi: 10.1007/s10902-017-9883-9.

[17] Lizote, S. A., Verdinelli, M. A. and Nascimento, S. Do., "Organizational commitment and job satisfaction: A study with municipal civil servants", Revista de Administração Pública, 51(6), pp. 947-967.,2017, doi: 10.1590/0034-7612156382.

[18] Maida, M. T., Riyanto, S. and Ali, H., "Effect of Job Satisfaction and Leadership Style towards Employee Productivity at PT. Asuransi Umum Bumiputera Muda 1967", Saudi Journal of Business and ..., (July), pp. 157-168, 2017, doi: 10.21276/sjbms.2017.2.3.7.

[20] Martono, S., Khoiruddin, M. and Wulansari, N. A., "Remuneration Reward Management System As a Drivern Factor of Employee Performance", International Journal of Business \& Society, 19(4), pp. 535-545, 2018.

[21] Okechukwu, W., "Influence of Training and Development, Employee Performance on Job Satisfaction Among the Staff", Journal of Technology Management \& Business, 14(1), pp. 1-16, 2017.

[22] Pahrudin, Cecep, Sandriana Marina, dan Lira Agusinta, "Kepemimpinan Etis, Karakteristik Pekerjaan, dan Kepuasan Kerja Karyawan Maskapai Penerbangan", Jurnal Manajemen Transportasi dan Logistik, Vol.5 No.2, p.117-128, 2018. 
[23] Pawirosumarto, S., Sarjana, P.K. and Gunawan, R., "The effect of work environment, leadership style, and organizational culture towards job satisfaction and its implication towards employee performance in Parador Hotels and Resorts, Indonesia", International Journal of Law and Management, 59(6), pp. 1337-1358, 2017, doi: https://doi.org/10.1108/IJLMA-10-2016-0085.

[24] Permadi, I. K. O., Landra, N. and Kusuma, I Gusti Agung Eka Teja Sudja, I. N, "The Impact Of Compensation And Work Environment Towards Job Satisfaction To Affect The Employee Performances", International Journal of Management and Commerce Innovations, 6(2), pp. 1248-1258, 2018.

[25] Setyaningsing, Yesa Martha Vita Simanungkalit Endang, "Pengaruh Gaya Kepemimpinan Terhadap Kepuasan Kerja Karyawan pada PT. Lion Mentari Airlines", UG Jurnal, Vol. 7 No. 06 p.30-33, 2013.

[26] Shobe, K. "Productivity Driven by Job Satisfaction, Physical Work Environment, Management Support and Job Autonomy", Business and Economics Journal, 09(02), 2018, doi: 10.4172/2151-6219.1000351.

[27] Srivastava, S. "Job Satisfaction and Organizational Commitment Relationship: Effect of Personality Variables", Vision: The Journal of Business Perspective, 17(2), pp. 159-167, 2013, doi: 10.1177/0972262912483529.

[28] Sule, E. T. and Saefullah, K., "Pengantar Manajemen". Cetakan 12, Jakarta: Prenadamedia Group, 2019. [29] Tampubolon, M. P., "Perilaku Keorganisasian", Ketiga, Bogor: Penerbit Ghalia Indonesia, 2012.

[30] Templer, K. J., "Five-Factor Model of Personality and Job Satisfaction: The Importance of Agreeableness in a Tight and Collectivistic Asian Society", Applied Psychology, 61(1), pp. 114-129, 2012, doi: 10.1111/j.1464-0597.2011.00459.x.

[31] Tepayakul, R. and Rinthaisong, I., "Job satisfaction and employee engagement among human resources staff of Thai Private Higher Education Institutions", Journal of Behavioral Science, 13(2), pp. 68-81. 2018.

[32] Vorina, A., Simonič, M. and Vlasova, M., "An Analysis of the Relationship Between Job Satisfaction and Employee Engagement", Economic Themes, 55(2), pp. 243-262. 2017, doi: 10.1515/ethemes-2017-0014.

[33] Wibowo, "Perilaku Dalam Organisasi", Ketiga, Depok: PT RajaGrafindo Persada, 2020. 